\title{
The role of grammar in learning to write: An interview with Joaquim Dolz and Carmen Rodríguez-Gonzalo, experts in writing didactics
}

El papel de la gramática en el aprendizaje de la escritura: Una entrevista con Joaquim Dolz y Carmen Rodríguez-Gonzalo, expertos en didáctica de la escritura

\author{
Alba Compte \\ Universitat Autònoma de Barcelona
}

\begin{abstract}
Joaquim Dolz holds a PhD in Educational Sciences and is Professor of Language Teaching at the University of Geneva (Switzerland). His research ranges from analysis of the teaching and learning process to teacher training. His work includes studies on the teaching of oral and written language, textual genres, and instructional sequences.

Carmen Rodríguez-Gonzalo holds a $\mathrm{PhD}$ in Language Education and is a former teacher in Language Arts at Secondary Education. She is an Associate Professor in the Department of Language and Literature Didactics at the University of Valencia (Spain). Her research focuses on the relationships between use and reflection on language, especially in the teaching of written language.
\end{abstract}

Keywords: Congram19; Grammar; Writing; L1 teaching and learning; Linguistics

\section{Resumen}

Joaquim Dolz es Doctor en Ciencias de la Educación y Catedrático en Didáctica de las Lenguas en la Universidad de Ginebra (Suiza). Su investigación abarca desde el análisis del proceso de enseñanza y aprendizaje hasta la formación del profesorado. Entre su trabajo destacan los estudios sobre la enseñanza de la lengua oral y escrita, los géneros textuales y las secuencias didácticas.

Carmen Rodríguez-Gonzalo es Doctora en Didáctica de la Lengua y Catedrática de Lengua y Literatura de Educación secundaria, así como profesora del Departamento de Didáctica de la Lengua y la Literatura en la Universidad de Valencia. Su investigación se centra en las relaciones entre uso y reflexión sobre la lengua, especialmente en la didáctica de la lengua escrita.

Palabras clave: Congram19; Gramática; Escritura; Enseñanza y aprendizaje de la L1; Lingüística 


\section{THE ROLE OF GRAMMAR IN LEARNING TO WRITE: AN INTERVIEW WITH JOAQUIM DOLZ AND CARMEN RODRÍGUEZ-GONZALO, EXPERTS IN WRITING DIDACTICS}

INTERVIEWER: Many researchers and members of the educational community have currently highlighted the importance of teaching writing strategies. From your viewpoint, what is the current state of this debate? How has competency-based curriculum influenced it and what is the role of grammar knowledge in it?

DOLZ: We must consider that learning to write is one of the fundamental purposes of teaching in general. Writing ensures access to complex forms of socialization important to every citizen's life. Writing is present in all school subjects and allows access to higher levels of schooling. I think these two reasons are sufficient to justify the central role of teaching writing in the curriculum. I remind you that the rate of school failure associated with reading and writing is quite high in general around the world. It is difficult to speak of the democratization of teaching without evoking writing. Our culture is a literate culture. Teaching to write also requires reflection on language and its formal uses. Reflection activities on the language allow developing a metalinguistic awareness. Awareness that, in principle, helps to have a more distanced relationship with language and discourse. I do not understand grammar as a manual of prescriptive rules. Grammar is a theory that tries to explain the operation of a given linguistic system. Beyond phonology, morphosyntax and lexicology, it extends to the set of metalinguistic activities both on the phrase and on the text. On the one hand, grammatical knowledge allows the development of a general culture about language. But also, on the other hand, reflective grammar activities on different dimensions of the language can help improve students' communication skills. In my opinion, it is not about being pro or against grammar teaching. The challenge is to ensure a better articulation between metalinguistic activities (analysis of the functioning of the language) and communication activities such as writing.

RODRÍGUEZ-GONZALO: Research on writing used to be primarily based on researching the strategies used by novice and expert writers in both writing and proofreading. Subsequent didactic investigations in natural classroom contexts have shown us the students' difficulties to represent writing as a social activity tied to different conventions (that is, to represent discursive genres) and to manage the writing process. Also, the importance and effectiveness of the didactic intervention in the classroom. We believe that the idea of writing as a complex process is already assumed in our Primary and Secondary schools. However, the idea of writing as a 
social activity which is embodied in various discursive genres, appears to be more confusing,. Text types have been generalized, which are prototypical text structures that combine in multiple ways across genres. In relation to the didactic intervention, there is still a long way to go before there is an adequate approach in classrooms, which guides students in the classroom during the learning of writing in all its phases.

In this context, the role of grammar knowledge remains controversial. In relation to writing, research tells us that its role is that of regulating the metalinguistic activity of the writer (also of the reader). Grammar knowledge, understood as the ability to reflect on the language and based on explicit knowledge about language, allows the speaker to adapt her expression to diverse needs. A competence-based curriculum (understood as the set of theoretical-practical knowledge, motivation and values that allow students to respond to complex demands and carry out various tasks appropriately) reinforces such an approach. With a fundamental condition, in our opinion: the adequate mediation of teachers.

INTERVIEWER: One of the intended focus to improve students' written competence is the (re)construction of the bridge between grammar and writing.

DOLZ: Exactly. The metaphor of the bridge seems correct to me. That is why I defend didactic engineering that facilitates the passage between grammar and writing as a two-way street. The assumption that linguistic studies will solve the problems of teaching writing and grammar is extremely naive. Regarding grammar studies, I am critical towards the simple linguistic applicationism and align with classroom research. Our research team in Switzerland gives great importance to the conception and experimentation of instructional sequences, in which grammar objects suitable for the study of texts are addressed. In other words, we contextualize the linguistic content within the discourse. This means grammatical activities aimed at improving the writing of diverse texts, which differs from decontextualized activities or lessons entirely focused on grammatical notions. Today the question is to know what grammatical studies allow these forms of articulation. The grammar of the sentence does not allow solving all the problems. Following your metaphor, I will say that it is not the only bridge and it is not always the most appropriate bridge. To approach writing, we also need to integrate sentence and text-level grammars. Teachers often select grammar topics to address spelling problems. But not all writing problems are of a spelling nature. Depending on the writing problem we are addressing and, the textual genre we are studying, the obstacles for the students will be different. The grammatical objects that particularly interest the 
teaching of writing are those that contribute solutions to the problems students must face when writing. As you will understand, I defend an open and partially eclectic perspective. Let me make myself clear. There is a plurality of linguistic theories. And not all linguistic perspectives seem relevant to me to establish a bridge between grammar and writing. I criticize strictly normative grammars. I defend, of course, descriptive studies and renewed pedagogical grammars, enriched by enunciative, pragmatic and textual contributions. But some linguistic descriptions are difficult to adapt to school. The transposition is not evident. And, there are still many areas of uncertainty in addressing writing problems. That is why I defend an open linguistic perspective that without losing scientific legitimacy adapts to teaching in different situations and responding to the needs of students of different ages. Research in language teaching has revealed how grammar is taught and how written production is taught. Thanks to the work carried out with colleague Bernard Schneuwly, we know better the dominant teaching practices and the difficulties we are facing when articulating a connection between grammar and writing. At the same time, new didactic engineering studies, such as those currently led by Ecaterina Bulea Bronckart, Roxane Gagnon, and Véronique Marmy, conceive and experiment with new didactic devices precisely to establish bridges where the observation of practices shows obstacles and limitations.

RODRÍGUEZ -GONZALO: Indeed, the role of grammar in the teaching of writing has to do with its regulatory role. The bridges between grammar and writing are possible, but they are not spontaneous or direct. They require a planned teaching that makes the grammatical concept conscious and useful, either in planning or in the revision of the writing that is being developed. In general terms, it is about connecting grammatical content with its uses in different areas (in academic writing, in creative writing, in writing to inform or for leisure or daily life uses) on the basis of activities of manipulation, comprehension and composition of texts, with attention to linguistic forms and our reflection on it. This knowledge is especially necessary in the formal uses and in the contrast of languages, although it is also present in activities speakers may occasionally be involved with, such as the use of dictionaries, translators and other linguistic resources that, now to a large extent, are available for everyone on the Net. Recent grammatical studies, from different theoretical perspectives, stress the importance of focusing onto the meaning. At one of the round tables of the conference on teaching grammar, Manuel Leonetti pointed out the need to present the basic notions as tools to understand how complex meanings are composed and communicated. The priority of the 
reflection on semantics must be central with the aim to avoid the predominance of identification tasks that are repeated year after year in current teaching.

INTERVIEWER: What concepts should we consider in a pedagogic grammar and how should we introduce them in the classroom?

DOLZ: It is difficult to answer your question briefly. And I am going to do it in a lapidary way. A language teacher must have a linguistic culture, know the linguistic foundations, must be able to establish a corpus of examples and be able to guide her students to verify the regularities and structures of the language (word classes, phrases and functions according to morphosyntax and semantics). But to approach writing, a strictly sentence-level approach is insufficient. We need to address the problems of structuring, cohesion, and textual coherence as well as their enunciative relationship in each communication context. The central notion to approach the teaching of writing is in my opinion that of discourse genre. The didactic modelling of genres (the dimensions of contextualization, planning, and textualization) seems essential to me to teach to write. The teacher also needs to be able to assess their students' language abilities when they produce a text. You also ask me to tell you how to introduce it into the classroom and I will be content to defend inductive methods, focused on the student's activity: writing various texts; analyzing corpus to discover the regularities of the genres; doing exercises designed to overcome writing obstacles; investigating to discover how the language works; rewriting and reformulating; reflecting on their own writing and the functioning of the system in the text being written.

RODRÍGUEZ-GONZALO: First, I would like to clarify that combining grammar and writing does not mean to dismiss specific work for grammar conceptualization (sometimes before, sometimes after writing work). The grammatical contents that intervene in the regulation of writing depend on the use of such contents. Some of them are necessary in the planning of the text, because they have to do with options of the enunciation (grammatical person of the addresser, modalization procedures that shape the author's position in the text, etc.) and others that give linguistic form to the organization of the ideas according to the text that we are preparing (tense correlations, connectors, cohesive mechanisms, etc.), some of them very complex and not very accessible to the conscience, except in revision activities. To use any of them, a conceptualization of the basic notions on which they are based (grammar categories, basic word groups, sentence structure) is required. This conceptualization, which should increase in depth and, therefore, in complexity, is a didactic work that must be done throughout compulsory 
education. As for the selection of grammatical content, it would be desirable, in my opinion, the collaboration between linguists, who provide theoretical knowledge, and specialists in language teaching, capable of carrying out the didactic transposition of that theoretical knowledge considering the conditions of learning abstraction and the purposes of teaching the language in compulsory education.

INTERVIEWER: The processes of conceptualization and of construction of meanings are often approached as two axes to articulate the relationship between grammar and writing. What tools are missing for future teachers to exploit grammar from these points of view?

DOLZ: In the first half of the last century, conceptualization was studied by Piaget to characterize a fundamental process of building higher psychic functions such as intelligence. Grammar is also presented as an organized system of concepts that have a practical equivalent in the schemes that govern speech and writing. Conceptualization can be independent of verbal actions. But it can also function as a second-degree thought that organizes inner operations, regulates action, and facilitates reflective acts. In a strictly Chomskyan position, it would not make much sense to approach the conceptualization and the process of construction of meanings as the backbone of writing, since language development is conceived as an emergency process of pre-programmed syntactic structures. In my view, the development of writing involves a learning process that goes far beyond the simple emergence of pre-programmed structures in the activity. Writing is learned through writing, but it is enacted through interacting and reflecting. The construction of meanings involves processes of semantic interpretation of linguistic signs and considers the values associated with communication situations and attributed to the recipient of the text being written. Significance is constructed in collective situations of interaction. And our ambition is to develop a conscious control of the processes of construction of meaning. Metalinguistic activities are activities for reflection on language and its use that seek conscious control and planning of the subject's own linguistic treatment processes.

Conceptualization is very important, but I believe the proposals for harmonization of concepts and grammatical terminology should be didactic. Teacher training must consider the didactic transposition processes of scientific concepts in writing learning situations. Having a solid grammatical knowledge is not enough. We need to know how to mobilize this knowledge in the classroom, how to develop teaching devices that allow the observation of the processes of construction of meaning, the identification of the obstacles of the students and the development of 
regulatory gestures and reflection activities that allow them help you have more conscious control of the operations involved in writing.

RODRÍGUEZ-GONZALO: From the viewpoint of language teaching, several studies focused on how different languages have explored the characteristics of a pedagogical grammar (Camps 2017; Camps and Milian, 2017). Also, institutions such as the Real Academia Española or the Institut d'Estudis Catalans (among others) have published good informative grammars in recent years, which start from the premise that the user already knows the basic concepts that are used in them. They are grammars aimed at all speakers "who, having received the first instruction in their primary and secondary studies, wish to better understand the functioning of their language" (RAE-ASALE, 2011). The recent publication of the Glosario de términos gramaticales (Glossary of grammatical terms, see Ignacio Bosque's contribution in Part 1 of this Special Issue 13(2) May/June 2020) (RAEASALE (2020) is also good news as an updated resource available to teachers. What is missing in this context? Two important conditions, in my opinion. On the one hand, there is a lack of proposals articulated with didactic criteria and organized with a progression of increasing complexity, from Primary Education to the end of Secondary Education. These types of proposals must be designed with the teacher in mind (not the linguist), since it is the teacher who will have to bring them to the classroom. And that task corresponds to the didactics of the language, which must show that grammar is used to get students used to reflecting on the languages they use. On the other hand, it is necessary to break the inertia of textbooks, which do not even allude to grammatical terms in the sections related to writing, turning grammar into an "isolated territory", oblivious to learning about writing and reading comprehension.

INTERVIEWER: The perception of students as double agents that must complete a writing task and, in turn, learn how to write is inspiring. Along these same lines, a double role of the student has been commented: as writer and as reviewer. How can we address each of these perspectives in the classroom?

DOLZ: In our book Producción escrita y dificultades de aprendizaje (Written production and learning difficulties) (Dolz Mestre et al. 2013) we propose to start from the observation of the writing situations and the analysis of the written products of the student. This allows to identify what their initial capacities are in terms of discursive and linguistic-discursive skills and their errors. The activities and exercises proposed in the instructional sequences depend on this initial assessment. Multiple situations of writing simulation of different discursive genres are 
proposed. The question of the authorship of the text and the enunciative role played by the student are taken into consideration. The activities of review, reformulation, rewriting and critical reflection on the writing processes are systematic.

RODRÍGUEZ-GONZALO: You say referring to Camps' studies, in the classroom, in relation to the teaching of writing, students play two roles at the same time: the role of writers who must produce texts as part of the teaching program, and the role of students who must learn to do it and whose writing ability increases, or should increase, as a result of teaching. In traditional approaches, the prototypical sequences of writing instruction are articulated around presentation-practice and feedback on the outcome. The shortcomings of this method, the results of which have seemed unsatisfactory for a long time, lie in the scant stimulation of reflection on the writing process, in the lack of clarity of the evaluation criteria of the texts, which only the teacher evaluates, in that students almost never detect or correct their mistakes and that, in short, feedback focuses on the product and not (or rarely) on the process (Rijlaarsdam and Couzijn, 2000). These deficiencies prevent students from learning in more ways than one: they are not encouraged to gather information about the quality of their writing activities or to build knowledge about their writing strategies. The resulting product may be satisfactory, but this does not guarantee that significant learning has occurred, that it can be used in new situations. In other words, the weak points of learning by doing are: a) lack of control activities (observation of one's behavior during the task); b) lack of evaluative activities (of the quality of the product itself or of writing process); c) lack of reflective activities (about one's own competence and about learning to write). In a traditional pedagogy these activities are left to the student's initiative and only good beginners are capable of learning in situations of this type, because they can do two tasks simultaneously: the task of writing the required texts and the task of learning how these texts are written while writing them. Most students, on the other hand, focus their attention and effort basically on solving the first task.

In response to these problems, different models of instructional sequences have been proposed inspired by project base learning (Rodríguez-Gonzalo, 2008). In these models, the students elaborate their texts in the classroom, generally in collaboration, with the constant guidance of the teacher, who guides the decisions that the students have to make as authors of their texts and relates them to necessary language learning activities. to support those decisions. In these instructional sequences it is essential that the student is aware of the process that is taking place in the classroom (formative evaluation). In other words, they are models that seek 
to enable the student to make linguistic decisions as the author of one's own texts and as a reviewer of the peers' texts (with the help of the teacher).

INTERVIEWER: The importance of the text revision is in general terms a point of agreement How to propose this revision to develop one's language awareness? How do we create that space for reflection?

DOLZ: Writing is rewriting. Great authors and expert writers rarely write without reviewing. However, beginning writers must learn to revise and rewrite. As I have said previously, our instructional sequences systematically propose activities to improve student writing including proofreading. To do this, we create specific working tools that develop different revision, reformulation, and rewriting strategies. Following the Vygostkian conception of the semiotic too as a mediator of psychic activity, we consider that such tools are a fundamental element to improve writing, exploiting its possibilities, enriching, and transforming it. Collective projects give meaning to writing situations. The first written production is always a collaborative outcome and an object of a debate among the students. The order of activities is organized in a way that allows a step-by-step progression of learning. All activities are subject to reflection and review. The final production generally includes guidelines prepared by the students themselves to retake, review, and improve the initial production. Writing activity and reflexivity are permanently associated. Interactions in the classroom are organized according to the obstacles identified by the teacher or by the students themselves and constitute the main way not only to improve writing but also to clarify the very process of subjectivation through writing.

RODRÍGUEZ-GONZALO: We are talking about revision as a writing phase, that is, as part of the process and not as a correction to the final text. Already since the 1980s, research highlighted that adolescent non-expert writers, if they sometimes detected some inadequacy in the text, were unable to explain the cause and, therefore, to change the erroneous form for an adequate one. Only an explicit knowledge of the grammatical structure involved allowed solving the problems. This situation shows us that, in learning to write, the student must have a certain degree of awareness of the linguistic requirements of the text, in order to be able to control it during its production and to be able to revise it. And this is where grammatical notions play their part. You cannot effectively review the correlation of verb tenses in a narrative, for example, without explicit knowledge about them. In the same way that it is not possible to assess whether the number of adjectives in a text is scarce or excessive without having the notion of what an adjective is 
and what it serves for. The problem is how this relationship is established between learning grammatical concepts and their use in writing activities. Currently, in the teaching units of most textbooks, the study of grammar is separated from writing and reading activities, in differentiated and unrelated work blocks. For example, the teaching of description and the teaching of the adjective appear uncoordinated and ignore each other (Rodríguez-Gonzalo and Zayas, 2017). In other words, it is expected that the student will find the links between the two, intuitively or casually. This only occurs in good learners, not in most students. The revision of grammatical aspects in the texts, as a formative evaluation activity with limited objectives, promotes an intense metalinguistic activity, which requires greater analysis and greater control than planning and textualization. That is, it is about reviewing in the texts, the grammatical aspects worked in the classroom in relation to the text that is being elaborated (the correlation of verb tenses in a narration, for example). In this way, students must turn to theoretical knowledge to analyze the problem and both the identification of the problem for its evaluation or modification to activate the metalinguistic consciousness, which is observed in the rewriting of their own compositions, rather than in the modifications of the texts they review (of which they are not authors).

INTERVIEWER: What requirements must the construction of a grammatical concept fulfil so that it is operative and contributes to the improvement of writing? How can we conceptualize without accumulating definitions?

DOLZ: A grammatical concept is a construction that accounts for the common characteristics of a series of linguistic facts. The conceptual field of grammar is marked by the history of school discipline. Its didactic transposition is complex. For example, scientific concepts and new notions of modern pedagogical grammars do not easily enter school. Sometimes the terminology is adopted and not really the concept. Traditional school grammar is grounded in school practices. It is also true that some concepts elaborated by the school system have gone back to the scientific field. Some school grammars preceded and anticipated linguistic studies. For a grammatical concept to be operational in teaching, it must be anchored in the previous conceptions or representations of the students, in what Vygotski called spontaneous concepts, which are not organized within a system. The conceptualization process can follow different paths. But we must combine a vision of the whole language system and the operationalization of the concept aimed at improving writing practices. Everyday concepts are born from the student's practice and, at school, they are systematized in an intellectual work and contribute to transforming the student's own practices and thinking. It is not a matter of accumulating 
concepts but of making them operational. It is about discovering and systematizing the concepts in a conceptual network about the functioning of the language. The concept is a starting point for reflective writing activity and at the same time an intellectual tool that confers explanatory power and linguistic security at the time of writing.

RODRÍGUEZ-GONZALO: Furthermore, the learning of concepts refers directly to the teaching of abstraction, to the need to categorize reality in its different manifestations. In language teaching, as in other disciplines, there does not seem to be a direct relationship between understanding a concept and knowing how to use it. Conceptualization is fundamentally a process of analysis, of decomposition of characterizing features, quite different from the integration of knowledge that use requires. According to the approaches of the teaching of abstraction, the operative structure of a concept requires a name, attributes, and examples. Learning does not end until the relationship between the concept and the example has been understood and can be generalized, that is, it can be recognized in new situations. This practical knowledge linked to understanding requires high analysis and control. Therefore, it is important that the student can propose examples, not simply identify them. Conceptualization speaks of denomination, not definition. As early as 1912, Rodolfo Lenz advocated the denomination and not the definition as a didactic method for teaching grammatical concepts (Lenz, 2012):

Therefore, young children should not be told: The verb is a word that ..., but: The word that in this sentence unites the attribute (Bello would name it "predicate") with the subject is called the verb. The word that says what the subject does here is called the verb. With the first system I am obliged, under pain of error, to enclose in my sentence all the functions of the verb, and I cannot do that. With the second, when I have seen the word in function, when I have examined and understood what it does in one sentence, immediately in another where it does not play the same role, I call the word I have just observed a verb; nothing else". (p. 9, italics in the original)

INTERVIEWER: The reflection on the use of terminology and the metalanguage creates a discussion that seems to be complemented with another discussion: the dialogue between the teaching and science of the language when analyzing what happens in the classroom. What is your opinion on this point? What is your position regarding pedagogical grammars?

DOLZ: The school system needs to adapt and harmonize linguistic terminology. Curricular progression requires coherence and continuity. Furthermore, we need a metalanguage that represents a common denominator for the different languages taught at school. We need pedagogical grammars in Spanish and Catalan 
that go beyond the proposals of the academies. I consider it very naive to promote school grammars under the exclusive guidance of language sciences. For this, dialogue between all the actors in the educational system is essential. Research in language teaching has advanced enormously in the last forty years. We know better the needs and difficulties of students of different ages. Important research has been done on the practice of grammar teaching and conceptualization processes in the classroom, and numerous teaching devices have been experimented. The pedagogical grammars performed in Quebec or in French-speaking Switzerland are an example of collaboration between language and didactic sciences. I also believe that teachers must be involved in the development of teaching materials and research.

RODRÍGUEZ-GONZALO: The use of metalanguage is necessary to refer to the language and to reflect on it. Metalanguage is present from the beginning in writing (terms such as "word", "letter", and "syllable" allow children to start speaking about the language they are beginning to represent in writing). The demands for terminology unification by teachers come from ancient times and, at times, have clashed with the demands for precision from one or another linguistic theory. A distinction must be made between the metalanguage needs of a specialist and those of students. Also, in this case a didactic transposition is required. For this reason, the dialogue between language teaching and language science is inescapable. From the field of Didactics, we welcome the resources that come to us from the language sciences (such as the glossaries or the informative grammars that we referred to earlier). And we would like the language sciences to understand the differences between these resources and the characteristics of a pedagogical or school grammar. This type of grammar must relate the object to the modes of teaching (the what, the how, and the what for), which means attending to the learning processes of students and also to the social purposes of teaching at each historical moment.

\section{REFERENCES}

Camps, A. \& Milian, M. (2017). Cap a una gramàtica per a l'ensenyament: definició i caracterització. Caplletra: revista internacional de filologia, 63, 217-243. https://doi.org/10.7203/Caplletra.63.10400

Camps, A. (2017). Reflexiones sobre la enseñanza y el aprendizaje de la gramática. In Camps, A. \& Ribas, T. (Coords.) El verbo y su enseñanza: hacia un modelo de enseñanza de la gramática basado en la actividad reflexiva (pp. 19-31). Barcelona: Octaedro.

Dolz Mestre, J., Gagnon, R., Mosquera Roa, S. y Sánchez Abchi, V. (2013). Producción escrita y dificultades de aprendizaje. Barcelona: Graó.

Lenz, R. (1912). Para qué enseñar gramática. [Key-note speech at the University of Chile in 2012]. https://revistas.uchile.cl/index.php/ANUC/article/viewFile/25606/26927 
RAE-ASALE (2011). Prólogo. Nueva gramática básica de la lengua española (p. XVII). Madrid: Espasa.

RAE-ASALE (2020). Glosario de términos gramaticales. Salamanca: Ediciones de la Universidad de Salamanca.

Rijlaarsdam, G. \& Couzijn, M. (2000). La estimulación de la metacognición en la enseñanza de la escritura. In M. Milian \& A. Camps, A. (Eds.). El papel de la actividad metalingüística en el aprendizaje de la escritura (pp. 215-258). Rosario: Homo Sapiens.

Rodríguez-Gonzalo, C. (Ed.) (2008). La lengua escrita y los proyectos de trabajo. Catarroja: Perifèric.

Rodríguez-Gonzalo, C. \& Zayas, F. (2017). La relación entre conocimientos gramaticales y el aprendizaje de prácticas discursivas: el adjetivo como ejemplo. Caplletra 63, 245-277. https://doi.org/10.7203/Caplletra.63.10401

\section{Alba COMPTE}

She is a graduate in Catalan Language and Literature Studies (UAB, 2018) and in 2019 she completed the official master's degree in Compulsory Secondary Education Teacher Training (UAB). She is currently a Catalan Language teacher at a secondary school in Sant Vicenç dels Horts (Barcelona). Her focuses of interest are the teaching of writing and its relationship with the development of reading comprehension and the interpretive capacity of students.

compterosich.alba@gmail.com https://orcid.org/0000-0001-8782-1386 


\section{EL PAPEL DE LA GRAMÁTICA EN EL APRENDIZAJE DE LA ESCRITURA: UNA ENTREVISTA CON JOAQUIM DOLZ Y CARMEN RODRÍGUEZ-GONZALO, EXPERTOS EN DIDÁCTICA DE LA ESCRITURA}

ENTREVISTADORA: Actualmente la enseñanza de la escritura y las estrategias empleadas en el aula para abordarla se han puesto en el punto de mira de la investigación y de la comunidad educativa. Desde su punto de vista, ¿cuál es la motivación y el estado actual de este debate? ¿Cómo ha podido influir un diseño curricular competencial y cuál sería el rol que ocuparía el conocimiento gramatical?

DOLZ: Tenemos que tomar en consideración que el aprendizaje de la escritura es una de las finalidades fundamentales de la enseñanza en general. La escritura asegura el acceso a formas de socialización complejas importantes para la vida de todo ciudadano. La escritura está presente en todas las materias escolares y permite acceder a mayores niveles de escolarización. Creo que esas dos razones son suficientes para justificar su importancia en los diseños curriculares. Le recuerdo que la tasa de fracaso escolar asociada a la lectura y a la escritura es bastante elevada en general en todos los países del mundo. Es difícil hablar de la democratización de la enseñanza sin evocar la escritura. Nuestra cultura es una cultura letrada.

Enseñar a escribir exige además una reflexión sobre la lengua y sus usos formales. Las actividades de reflexión sobre la lengua permiten desarrollar una conciencia metalingüística. Conciencia que, en principio, ayuda a tener una relación más distanciada con el lenguaje y el discurso. No entiendo la gramática como un manual de normas prescriptivas. La gramática es una teoría que trata de explicar el funcionamiento de un sistema lingüístico dado. Más allá de la fonología, la morfosintaxis y la lexicología, se extiende al conjunto de actividades metalingüísticas tanto sobre la frase como sobre el texto. Por un lado, el conocimiento gramatical permite desarrollar una cultura general sobre la lengua. Pero, además, por otro lado, las actividades reflexivas gramaticales sobre las diferentes dimensiones de la lengua pueden contribuir a mejorar las capacidades comunicativas de los alumnos. A mi entender no se trata de estar a favor o en contra de una enseñanza gramatical. El desafío es asegurar una mejor articulación entre las actividades metalingüísticas (análisis del funcionamiento de la lengua) y las actividades de comunicación como la escritura.

RODRÍGUEZ-GONZALO: La investigación sobre la escritura se fundamentó en primer lugar en las investigaciones sobre las estrategias de escritores noveles y expertos tanto al escribir como al revisar. Las investigaciones didácticas posteriores en contexto natural de aula nos han mostrado las dificultades de los 
estudiantes para representarse la escritura como actividad social sujeta a diferentes convenciones (es decir, para representarse los géneros discursivos más alejados de su experiencia directa) y para gestionar la realización del texto. También, la importancia y la efectividad de la intervención didáctica en el aula. En nuestras escuelas e institutos podemos considerar asentada la idea de la escritura como un proceso complejo. Más confusa aparece todavía la idea de la escritura como actividad social, que se plasma en géneros discursivos diversos. Se han generalizado los tipos de texto, que son estructuras textuales prototípicas que se combinan de múltiples maneras en los distintos géneros. En relación con la intervención didáctica, todavía falta mucho para que en las aulas haya un adecuado planteamiento didáctico, que guíe a los estudiantes en el aula durante el aprendizaje de la escritura en todas sus fases.

En este contexto, sigue siendo polémico el papel del conocimiento gramatical. En relación con la escritura, la investigación nos dice que su papel es el de instrumento regulador de la actividad metalingüística del escritor (también del lector). El conocimiento gramatical, entendido como capacidad de reflexionar sobre la lengua a partir de conocimientos explícitos sobre ella, permite al hablante adaptar su expresión a necesidades diversas.

Un diseño curricular que pone el énfasis en las competencias, entendidas como el conjunto de saberes teórico-prácticos, motivación y valores que permiten al estudiante responder a demandas complejas y lleva a cabo tareas diversas de forma adecuada, es un refuerzo a estos planteamientos. Con una condición fundamental, a nuestro juicio, que el currículo se traduzca en intervenciones didácticas en las aulas por parte de maestros y profesores que ayuden a los alumnos a alcanzar el dominio competencial que se persigue.

ENTREVISTADORA: Una de las soluciones planteadas ante la necesidad de mejorar la competencia escrita es la (re)elaboración del puente entre gramática y escritura.

DOLZ: Exactamente. La metáfora del puente que evoca en su pregunta me parece acertada. Por eso yo defiendo una ingeniería didáctica que facilite el pasaje entre la gramática y la escritura. Pensar que los estudios lingüísticos recientes resuelven los problemas de la enseñanza es de una ingenuidad enorme. Me habla de estudios gramaticales y yo -crítico con el simple aplicacionismo lingǘstico- le hablaré de la importancia de los estudios didácticos recientes. Nuestro equipo de investigación en Suiza da una importancia mayor a la concepción y experimentación de secuencias didácticas donde se abordan objetos gramaticales adecuados al 
estudio de textos. Dicho de otra manera, contextualizamos los hechos de lengua en el discurso. Se trata de actividades gramaticales integradas en un trabajo destinado a mejorar la escritura de textos diversos, una reflexión gramatical distinta a las actividades descontextualizadas o a las lecciones que se concentran sobre las nociones gramaticales.

Hoy la cuestión es saber qué estudios gramaticales permiten esas formas de articulación. La gramática de la frase no permite resolver todos los problemas. Siguiendo su metáfora diré que no es el único puente y no siempre es el puente más adecuado. Para abordar la escritura, precisamos también asociar la gramática de la frase y la gramática del texto.

A menudo los profesores seleccionan los temas gramaticales para abordar los problemas ortográficos. Pero no todos los problemas de escritura son ortográficos. Según el problema de escritura que abordemos, el género textual que estudiemos, los obstáculos que encuentren los alumnos van a ser distintos. Los objetos gramaticales que interesan particularmente a la didáctica de la escritura son aquellos que contribuyen a resolver los problemas de producción escrita de los alumnos.

Como comprenderá, yo defiendo una perspectiva abierta y parcialmente ecléctica. Me explico. Existe una pluralidad de teorías lingüísticas. Y no todas las perspectivas lingüísticas me parecen pertinentes para establecer un puente entre gramática y escritura. Critico las gramáticas estrictamente normativas. Defiendo por supuesto los estudios descriptivos y las gramáticas pedagógicas renovadas, enriquecidas por los aportes enunciativos, pragmáticos y textuales. Pero, algunas descripciones lingüísticas son difíciles de adaptar a la escuela. La transposición no es evidente. Y, para abordar los problemas de escritura, continúan existiendo muchas zonas de incerteza. Por eso defiendo una perspectiva lingüística abierta que, sin perder legitimidad científica, se adapte a las situaciones de enseñanza y a las necesidades de los alumnos de diferentes edades.

La investigación en didáctica de las lenguas ha puesto en evidencia cómo se enseña la gramática y cómo se enseña la producción escrita. Gracias a los trabajos realizados con Bernard Schneuwly conocemos mejor las prácticas docentes dominantes y las dificultades que representa la articulación entre la gramática y la escritura. Paralelamente, los nuevos trabajos de ingeniería didáctica, como los dirigidos actualmente por Ecaterina Bulea Bronckart, Roxane Gagnon y Véronique Marmy, conciben y experimentan nuevos dispositivos didácticos justamente para establecer puentes donde la observación de las prácticas muestra obstáculos y fronteras. 
RODRÍGUEZ-GONZALO: Como he dicho antes, el papel de la gramática en la enseñanza de la escritura tiene que ver con su papel regulador. Los puentes entre gramática y escritura son posibles, pero no son espontáneos ni directos. Requieren de una enseñanza planificada que haga consciente y útil el concepto gramatical bien en la planificación, bien en la revisión del escrito que se está desarrollando. En líneas generales, se trata de conectar los contenidos gramaticales con sus usos en diferentes ámbitos (escritura académica, creativa, para informar o para usos del ocio o de la vida cotidiana) y de plantear actividades de aprendizaje (de manipulación, de comprensión y de composición de textos) que consideren la atención a la forma y la reflexión sobre ella. Este conocimiento es especialmente necesario en los usos formales y en el contraste de lenguas, aunque también está presente en actividades habituales de los hablantes, como el uso de diccionarios, traductores y otras ayudas lingüísticas que, ahora en buena medida, están a disposición de todos en Internet.

Los estudios gramaticales recientes, desde distintas perspectivas teóricas, inciden en la importancia de atender al significado. En la mesa redonda del Congram19, Manuel Leonetti señaló la necesidad de presentar las nociones básicas como herramientas para entender cómo se componen y se comunican significados más o menos complejos. La prioridad de la reflexión del significado ha de estar presente en la manera de plantear ejercicios y tareas prácticas y en la forma de hacer progresar la enseñanza de las nociones. Se trata de evitar el predominio de las tareas de identificación que se repiten curso tras curso en la enseñanza actual.

ENTREVISTADORA: ¿Qué conceptos deberíamos tener en cuenta para la enseñanza y cómo deberíamos introducirlos en el aula?

DOLZ: Es difícil responder brevemente a su pregunta. Y lo voy a hacer de manera lapidaria. Un profesor de lengua debe disponer de una cultura lingüística, conocer los fundamentos lingüísticos, debe poder establecer un corpus de ejemplos y poder guiar a sus alumnos para verificar las regularidades y las estructuras de la lengua (clases gramaticales, grupos y funciones según criterios morfosintácticos y semánticos). Pero, para abordar la escritura, una gramática estrictamente frástica es insuficiente. Necesitamos abordar los problemas de estructuración, de cohesión y de coherencia textuales, así como su puesta en relación enunciativa en un contexto de comunicación determinado. La noción central para abordar la enseñanza de la escritura es, a mi entender, la noción de género textual. La modelización didáctica de los géneros textuales (dimensiones enseñables de la contextualización, la planificación y la textualización) me parece esencial para poder enseñar la 
producción escrita. El profesor precisa además poder evaluar las capacidades de lenguaje de sus alumnos cuando producen un texto.

Usted me pide además que le diga cómo introducirlo en el aula y me contentaré con defender los métodos inductivos, centrados en la actividad del alumno: escribiendo textos diversos; analizando corpus para descubrir las regularidades de los géneros; realizando ejercicios destinados a superar los obstáculos de escritura; investigando para descubrir el funcionamiento de la lengua; reescribiendo y practicando la reformulación; reflexionando sobre su propia escritura y el funcionamiento del sistema en el texto que se está escribiendo.

RODRÍGUEZ-GONZALO: En primer lugar, me gustaría aclarar que aunar el trabajo de gramática y escritura no significa que no sea necesario un trabajo específico para la conceptualización gramatical (a veces previo, a veces posterior al trabajo de escritura).

Los contenidos gramaticales que intervienen en la regulación de la escritura están en función de su uso. Hay contenidos necesarios en la planificación del texto, porque tienen que ver con opciones de la enunciación (persona gramatical del emisor, procedimientos de modalización que dan forma a la posición del autor en el texto...) y otros que dan forma lingüística a la organización de las ideas según el texto que estemos elaborando (correlaciones temporales, incisos, conectores, mecanismos de mantenimiento de la referencia...), algunos muy complejos y poco accesibles a la conciencia, salvo en actividades de revisión.

Para poder utilizar cualquiera de ellos hace falta una conceptualización de las nociones básicas en que se apoyan (categorías gramaticales, grupos de palabras básicos, estructura oracional). Esta conceptualización, que habría de ir aumentando en profundidad y, por tanto, en complejidad, es un trabajo didáctico que se ha de hacer durante toda la educación obligatoria.

En cuanto a la selección de los contenidos gramaticales, sería deseable, a mi juicio, la colaboración entre lingüistas, que aporten el saber teórico, y especialistas en didáctica de la lengua, capaces de realizar la transposición didáctica de ese saber teórico teniendo en cuenta las condiciones del aprendizaje de la abstracción y las finalidades de la enseñanza de la lengua en la educación obligatoria.

ENTREVISTADORA: Durante la mesa redonda se trataron los procesos de conceptualización y de construcción de significados como dos ejes para vertebrar la relación entre gramática y escritura. ¿Qué herramientas les faltan a los futuros docentes para explotar la gramática desde estos puntos de vista? 
DOLZ: En la primera mitad del siglo pasado, la conceptualización fue estudiada por Piaget para caracterizar un proceso fundamental de la construcción de funciones psíquicas superiores como la inteligencia. También la gramática se presenta como un sistema organizado de conceptos que tienen un equivalente práctico en los esquemas que rigen el habla y la escritura. La conceptualización puede ser independiente de las acciones verbales. Pero también puede funcionar como un pensamiento de segundo grado que organiza las operaciones interiores, regula la acción y facilita los actos reflexivos. En una posición estrictamente chomskyana, no tendría mucho sentido abordar la conceptualización y el proceso de construcción de significados como ejes vertebradores de la escritura ya que el desarrollo del lenguaje se concibe como un proceso de emergencia de estructuras sintácticas preprogramadas.

A mi modo de ver, el desarrollo de la escritura implica un proceso de aprendizaje que va mucho más allá de la simple emergencia de estructuras preprogramadas en la actividad. A escribir se aprende escribiendo, pero se realiza interactuando y reflexionando. La construcción de significaciones implica procesos de interpretación semántica de signos lingüísticos y toma en cuenta los valores asociados a las situaciones de comunicación y atribuidos al destinatario del texto que se está escribiendo. La significación se construye en situaciones colectivas de interacción. Y nuestra ambición es desarrollar un control consciente de los procesos de construcción de la significación. Las actividades metalingüísticas son actividades de reflexión sobre el lenguaje y su utilización que buscan un control consciente y de planificación de los propios procesos de tratamiento lingüístico de los sujetos.

La conceptualización es muy importante, pero a mi entender las propuestas de armonización de los conceptos y de la terminología gramatical deben ser didácticas. La formación del profesorado debe tomar en consideración los procesos de transposición didáctica de los conceptos científicos en las situaciones de aprendizaje de la escritura. No basta con tener unos sólidos conocimientos gramaticales. Precisamos saber cómo movilizar esos conocimientos en el aula, cómo desarrollar dispositivos de enseñanza que permitan la observación de los procesos de construcción de la significación, la identificación de los obstáculos de los alumnos y el desarrollo de gestos de regulación y de actividades de reflexión que les ayuden a tener un mayor control consciente de las operaciones implicadas en la escritura.

RODRÍGUEZ-GONZALO: La didáctica de la lengua ha investigado sobre las características de una gramática escolar o pedagógica (Camps 2017; Camps and Milian, 2017) y se han hecho ejemplificaciones parciales en distintas lenguas. 
También desde instituciones como la Real Academia Española o el Institut d'Estudis Catalans (entre otras) se han propuesto en los últimos años buenas gramáticas divulgativas, que parten de la premisa de que el usuario ya conoce los conceptos básicos que en ellas se manejan. Son gramáticas dirigidas a todos los hablantes "que, habiendo recibido la primera instrucción en sus estudios de primaria y secundaria, deseen acercarse a comprender mejor el funcionamiento de su lengua" (RAE-ASALE, 2011). Es una buena noticia, asimismo, la reciente publicación del Glosario de términos gramaticales (ver Bosque, en la primera parte de este mismo monográfico, 13.2) (RAE-ASALE(2020), como recurso actualizado a disposición de los docentes.

En este contexto, ¿qué falta? Dos condiciones importantes, a mi juicio. Por un lado, faltan propuestas articuladas con criterios didácticos y organizadas con una progresión de complejidad creciente, desde la Educación Primaria hasta el final de la Educación Secundaria Obligatoria. Este tipo de propuestas han de estar diseñadas pensando en los maestros y profesores que han de llevarlas al aula, no en los lingüistas. Y esa tarea corresponde a la didáctica de la lengua, que ha de mostrar que la gramática sirve para habituar a los alumnos a reflexionar sobre las lenguas que utilizan. Por otro lado, hace falta romper la inercia de los libros de texto, que ni siquiera aluden a los términos gramaticales en los apartados vinculados a la escritura, convirtiendo la gramática en un "territorio aislado", ajeno a los aprendizajes sobre expresión y comprensión.

ENTREVISTADORA: Resulta muy enriquecedora para entender la complejidad del aula la percepción de los alumnos como un agente doble que debe completar una tarea de escritura y, a su vez, aprender cómo escribir. En esta misma línea se ha comentado un doble rol del alumno: como escritor/autor y como revisor. ¿Qué podemos trabajar desde cada una de estas perspectivas?

DOLZ: En nuestro libro Producción escrita y dificultades de aprendizaje (Dolz Mestre et al. 2013), proponemos partir de la observación de las situaciones de producción y del análisis de las producciones escritas del alumno para identificar cuáles son las capacidades de acción, discursivas y lingüístico-discursivas iniciales y a partir de los errores. Las actividades y los ejercicios propuestos en las secuencias didácticas dependen de una evaluación inicial del alumno. Se proponen múltiples situaciones de simulación de escritura de géneros escritos diferentes. Se toma en consideración la cuestión de la autoría del texto y del rol enunciativo que juega el alumno. Las actividades de revisión, reformulación, reescritura y reflexión crítica sobre los propios procesos de escritura son sistemáticas. 
RODRÍGUEZ-GONZALO: En el aula, en relación con la enseñanza de la escritura, los alumnos desempeñan a la vez dos papeles: el papel de escritor, que debe producir textos como parte del programa de enseñanza y el papel de estudiante, que ha de aprender a hacerlo y cuya habilidad para escribir aumenta, o habría de aumentar, como resultado de la enseñanza.

En los planteamientos tradicionales, las secuencias prototípicas de enseñanza de la escritura se articulan en torno a presentación-práctica-feedback o retroalimentación sobre los resultados. Las deficiencias de este método, cuyos resultados parecen poco satisfactorios desde hace tiempo, radican en la escasa estimulación de la reflexión sobre el proceso de redacción, en la falta de claridad de los criterios de valoración de los textos, que evalúa únicamente el docente, en que los alumnos casi nunca detectan o corrigen sus fallos y en que el feedback se concentra más en el producto que en el proceso (Rijlaarsdam and Couzijn, 2000). Estas deficiencias restringen el aprendizaje de los alumnos en más de un sentido: no se les estimula para reunir información sobre la calidad de sus actividades de escritura o para construir un saber sobre sus estrategias para escribir. El producto que resulta puede ser más o menos satisfactorio, pero esto no garantiza que se haya producido un aprendizaje significativo, que pueda ser utilizado en situaciones nuevas. Es decir, los puntos débiles del aprender haciendo son: a) carencia de actividades de control (de observación del propio comportamiento durante la tarea); b) carencia de actividades evaluativas (de la calidad del propio producto o proceso de escritura); c) carencia de actividades reflexivas (sobre la propia competencia y sobre el aprendizaje de la escritura). En una pedagogía tradicional estas actividades quedan a la iniciativa del estudiante y solo los buenos principiantes son capaces de aprender en situaciones de este tipo, porque pueden realizar una doble tarea: escribir los textos requeridos y aprender sobre cómo se escriben mientras lo hacen. La mayoría de los estudiantes, en cambio, concentra la atención y el esfuerzo en solventar la primera tarea.

Como respuesta a estos problemas, se han planteado distintos modelos de secuencias didácticas, planteadas como proyectos de lengua (Rodríguez-Gonzalo, 2008) (de escritura, de expresión oral). En estos modelos, los estudiantes elaboran sus textos en el aula, generalmente en colaboración, con la guía constante del docente, que guía las decisiones que los estudiantes han de tomar como autores de sus textos y las relaciona con actividades de aprendizaje lingüístico, necesarias para sustentar esas decisiones. En estas secuencias didácticas es fundamental que el alumno sea consciente del proceso que se está desarrollando en el aula (evaluación formativa). Es decir, son modelos que persiguen que el alumno pueda tomar 
decisiones lingüísticas como autor de sus textos y también como revisor, con la ayuda del docente, de los textos de sus iguales.

ENTREVISTADORA: La importancia de la revisión del texto fue un punto de acuerdo en la mesa redonda. ¿Cómo planteamos esta revisión para desarrollar una conciencia lingüística? ¿Cómo creamos ese espacio de reflexión?

DOLZ: Escribir es reescribir. Los grandes autores y los escritores expertos raramente escriben sin revisar. Sin embargo, los escritores principiantes tienen que aprender a revisar.

Como he dicho anteriormente, nuestras secuencias didácticas proponen sistemáticamente actividades para mejorar la escritura de los alumnos que incluyen la revisión. Para ello creamos herramientas de trabajo particulares que desarrollan estrategias diversas de revisión, reformulación y reescritura. Siguiendo la concepción vigotskiana de la herramienta semiótica, mediadora de la actividad psíquica, consideramos que esta es un elemento fundamental para mejorar la escritura, explotando sus posibilidades, enriqueciéndola y transformándola.

Los proyectos colectivos dan sentido a las situaciones de producción. La primera producción escrita de los alumnos es compartida, evaluada y objeto de un primer debate entre los alumnos. El orden de las actividades se organiza de manera que permita una progresión paso a paso de los aprendizajes. Todas las actividades son objeto de reflexión y de revisión. La producción final incluye generalmente pautas elaboradas por los propios alumnos para retomar, revisar y mejorar la producción inicial.

La actividad de escritura y la reflexividad están permanentemente asociadas. Las interacciones en el aula se organizan en función de los obstáculos identificados por el profesor o por los propios alumnos y constituyen la vía principal no sólo para mejorar la escritura sino también para aclarar el proceso mismo de subjetivación a través de la escritura.

RODRÍGUEZ-GONZALO: Hablamos de la revisión como fase de la escritura, es decir, como parte del proceso y no como corrección del texto final. Ya desde los años ochenta del siglo pasado, la investigación puso de relieve que los escritores no expertos adolescentes, si en ocasiones detectaban alguna inadecuación en el texto, eran incapaces de explicar la causa y, por lo tanto, de cambiar la forma errónea por otra adecuada. Solo un conocimiento explícito de la estructura gramatical implicada permitía resolver los problemas. 
Esta situación nos muestra que, en el aprendizaje de la escritura, el alumno ha de tener cierto grado de conciencia sobre los requerimientos lingǘsticos del texto, para poder controlarlo durante su realización y para poder revisarlo. Y en este terreno es donde las nociones gramaticales desempeñan su papel. No se puede revisar la correlación de tiempos verbales en una narración, por ejemplo, sin conocerlos. De la misma forma que no se puede valorar si la adjetivación de un texto es escasa o excesiva sin disponer de la noción de adjetivo.

El problema es cómo se establece esa relación entre el aprendizaje de los conceptos gramaticales y su utilización en actividades de escritura. En la actualidad, en las unidades didácticas de la mayoría de los libros de texto, el estudio de la gramática está separado de las actividades de escritura y de lectura, en bloques de trabajo diferenciados y sin relación entre sí. Por ejemplo, la enseñanza de la descripción y la enseñanza del adjetivo aparecen descoordinados y se ignoran mutuamente (Rodríguez-Gonzalo y Zayas, 2017). Es decir, se espera que sea el alumno quien, de forma intuitiva o casual, encuentre los vínculos entre ambos. Esto solo ocurre en los buenos aprendices, no en la mayoría de los alumnos.

La revisión de aspectos gramaticales en los textos, como actividad de evaluación formativa con objetivos delimitados, promueve una intensa actividad metalingüística, que exige mayor análisis y control que la planificación y la textualización. Es decir, se trata de revisar en los textos los aspectos gramaticales trabajados en el aula en relación con el texto que se está elaborando (la correlación de tiempos verbales en una narración, por ejemplo). De esta manera, los estudiantes han de acudir al saber teórico para analizar el problema establecido y tanto la identificación del problema como su evaluación o modificación activan la conciencia metalingüística, que se observa en la reescritura de sus propias composiciones, más que en las modificaciones de los textos que revisan (de los que no son autores).

ENTREVISTADORA: ¿Qué requisitos debe cumplir la construcción de un concepto gramatical para que este sea operativo y contribuya a la mejora de la escritura? ¿Cómo podemos conceptualizar sin acumular definiciones?

DOLZ: Un concepto gramatical es una construcción que da cuenta de las características comunes de una serie de hechos lingüísticos. El campo conceptual de la gramática está marcado por la historia de la disciplina escolar. Su transposición didáctica es compleja. Por ejemplo, los conceptos científicos y las nuevas nociones de las gramáticas pedagógicas modernas no entran con facilidad en la escuela. Algunas veces se adopta la terminología y no realmente el concepto. La gramática tradicional escolar está sedimentada en las prácticas escolares. También es 
verdad que algunos conceptos elaborados por el sistema escolar han remontado al campo científico. Algunas gramáticas escolares precedieron y anticiparon estudios lingüísticos.

Para que un concepto gramatical sea operativo en la enseñanza, debe anclarse en las concepciones o representaciones anteriores de los alumnos, en lo que Vigotski llamaba conceptos cuotidianos, que no están organizados en un sistema. El proceso de conceptualización puede seguir trayectorias diferentes. Pero tenemos que combinar una visión del conjunto del sistema de la lengua y la operacionalización del concepto destinada a mejorar las prácticas de la escritura. Los conceptos cuotidianos nacen de la práctica del alumno y, en la escuela, se sistematizan en un trabajo intelectual y contribuyen a transformar las prácticas y el propio pensamiento del alumno.

No se trata de acumular conceptos sino de hacerlos operativos. Se trata de descubrir y sistematizar los conceptos en una red conceptual sobre el funcionamiento de la lengua. El concepto es un punto de partida de la actividad reflexiva sobre la escritura y al mismo tiempo una herramienta intelectual que confiere poder explicativo y seguridad lingüística en el momento de escribir.

RODRÍGUEZ-GONZALO: El aprendizaje de conceptos remite directamente a la enseñanza de la abstracción, a la necesitad de categorizar la realidad en sus distintas manifestaciones. En la enseñanza de la lengua, como en otras disciplinas, no parece haber una relación directa entre comprender un concepto y saber utilizarlo en las propias producciones.

La conceptualización es fundamentalmente un proceso de análisis, de descomposición de rasgos caracterizadores, bien diferente de la integración de saberes que requiere el uso. Según los planteamientos de la enseñanza de la abstracción, la estructura operatoria de un concepto requiere de denominación, atributos y ejemplos. El aprendizaje no finaliza hasta que la relación entre el concepto y el ejemplo se ha comprendido y se puede generalizar, es decir, se puede reconocer en situaciones nuevas. Este saber práctico vinculado a la comprensión necesita de un alto análisis y control. Por ello es importante que el alumno pueda proponer ejemplos, no simplemente identificarlos.

La conceptualización habla de denominación, no de definición. Ya en 1912, Rodolfo Lenz propugnaba la denominación y no la definición como método didáctico para la enseñanza de los conceptos gramaticales (Lenz, 2012): 
No se diga pues a niños chicos: El verbo es una palabra que..., sino: La palabra que en esta frase une el atributo (Bello diría el "predicado") con el sujeto se llama verbo. La palabra que dice lo que aquí hace el sujeto se llama verbo. Con el primer sistema, estoy obligado, so pena de error, de encerrar en mi frase todas las funciones del verbo, y no lo puedo. Con el segundo, cuando lo he visto en función, cuando he examinado y comprendido lo que hace en una frase, enseguida en otra donde no desempeña el mismo papel, llamo verbo a la palabra que acabo de observar; nada más. (p. 9, cursiva en el original)

ENTREVISTADORA: La reflexión sobre uso de la terminología y del metalenguaje crea un debate que parece complementarse con otra discusión: el diálogo entre la didáctica y las ciencias del lenguaje a la hora de analizar qué ocurre en el aula. ¿Cuál es su opinión en este punto? ¿Cuál es su postura ante las gramáticas pedagógicas?

DOLZ: El sistema escolar necesita adaptar y armonizar la terminología lingüística. La progresión curricular exige coherencia y continuidad. Además, precisamos un metalenguaje que represente un común denominador para las diferentes lenguas enseñadas en la escuela. Necesitamos gramáticas pedagógicas de referencia en castellano y en catalán que vayan más allá de las propuestas de las academias. Considero muy ingenuo promover gramáticas escolares bajo la orientación exclusiva de las ciencias del lenguaje. Para ello, el diálogo entre todos los actores del sistema educativo es indispensable.

La investigación en didácticas de las lenguas ha avanzado enormemente los cuarenta últimos años. Conocemos mejor las necesidades y las dificultades de los alumnos de diferentes edades. Se han realizado investigaciones importantes sobre la práctica de la enseñanza gramatical, los procesos de conceptualización en el aula y se han experimentado numerosos dispositivos de enseñanza. Las gramáticas pedagógicas realizas en Quebec o en la Suiza francófona son un ejemplo de colaboración entre las ciencias del lenguaje y la didáctica. Yo creo además que hay que implicar al profesorado en la elaboración de materiales didácticos y en la investigación.

RODRÍGUEZ-GONZALO: El uso de metalenguaje es necesario para referirnos a la lengua y para reflexionar sobre ella. El metalenguaje está presente desde los inicios en la escritura (términos como palabra, letra, sílaba permiten a los niños empezar a hablar sobre la lengua que están empezando a representar por escrito).

Las demandas de unificación terminológica por parte de los docentes vienen de antiguo y, en ocasiones, han chocado con las exigencias de precisión desde una u otra teoría lingüística. Hay que distinguir entre las necesidades de metalenguaje 
de un especialista y las de los estudiantes. Es decir, también en este caso se requiere de transposición didáctica. Por ello, el diálogo entre la didáctica de la lengua y las ciencias del lenguaje es ineludible. Desde la didáctica damos la bienvenida a los recursos que nos llegan de las ciencias del lenguaje (como los glosarios o las gramáticas divulgativas a que nos referíamos antes). Y nos gustaría que desde las ciencias del lenguaje se entendieran las diferencias que hay entre estos recursos y las características de una gramática pedagógica, o escolar. Este tipo de gramáticas han de relacionar el objeto con los modos de enseñanza (el qué y el cómo enseñar), lo que supone atender a los procesos de aprendizaje de los estudiantes y también a las finalidades sociales de la enseñanza en cada momento histórico.

\section{REFERENCIAS}

Camps, A. (2017). Reflexiones sobre la enseñanza y el aprendizaje de la gramática. En Camps, A. y Ribas, T. (Coords.) El verbo y su enseñanza: hacia un modelo de enseñanza de la gramática basado en la actividad reflexiva (pp. 19-31). Barcelona: Octaedro.

Camps, A. y Milian, M. (2017). Cap a una gramàtica per a l'ensenyament: definició i caracterització. Caplletra: revista internacional de filologia, 63, 217-243. https://doi.org/10.7203/Caplletra.63.10400

Dolz Mestre, J., Gagnon, R., Mosquera Roa, S. y Sánchez Abchi, V. (2013). Producción escrita y dificultades de aprendizaje. Barcelona: Graó.

Lenz, R. (1912). Para qué enseñar gramática. [Conferencia dictada en la Universidad de Chile en 1912]. https://revistas.uchile.cl/index.php/ANUC/article/viewFile/25606/26927

RAE-ASALE (2011). Prólogo. Nueva gramática básica de la lengua española (p. XVII). Madrid: Espasa.

RAE-ASALE (2020). Glosario de términos gramaticales. Salamanca: Ediciones de la Universidad de Salamanca.

Rijlaarsdam, G. y Couzijn, M. (2000). La estimulación de la metacognición en la enseñanza de la escritura. En M. Milian y A. Camps, A. (Eds.). El papel de la actividad metalingüística en el aprendizaje de la escritura (pp. 215-258). Rosario: Homo Sapiens.

Rodríguez-Gonzalo, C. (Ed.) (2008). La lengua escrita y los proyectos de trabajo. Catarroja: Perifèric.

Rodríguez-Gonzalo, C. y Zayas, F. (2017). La relación entre conocimientos gramaticales y el aprendizaje de prácticas discursivas: el adjetivo como ejemplo. Caplletra 63, 245-277. https://doi.org/10.7203/Caplletra.63.10401 


\section{Alba COMPTE}

Es graduada en Estudios de Lengua y Literatura Catalanas (UAB, 2018) y en 2019 realizó el Máster oficial en Formación de Profesorado de Educación Secundaria Obligatoria (UAB). Actualmente es profesora de Lengua Catalana en un instituto de educación secundaria de Sant Vicenç dels Horts (Barcelona). Sus focos de interés son la enseñanza de la escritura y su relación con el desarrollo de la comprensión lectora y la capacidad interpretativa de los alumnos.

compterosich.alba@gmail.com https://orcid.org/0000-0001-8782-1386

Compte, Alba (2020). The role of grammar in learning to write: An interview with Joaquim Dolz and Carmen Rodríguez-Gonzalo, experts in writing didactics. Bellaterra Journal of Teaching \& Learning Language \& Literature, 13(3), e855. https://doi.org/10.5565/rev/jtl3.855 